\title{
Mechanism-based Drug Therapy of Inflammatory Bowel Disease With Special Reference to Rheumatic Disease
}

\author{
Jae Jun Park, M.D., Ph.D. \\ Division of Gastroenterology, Department of Internal Medicine, Yonsei University College of Medicine, Seoul, Korea
}

\begin{abstract}
Inflammatory bowel disease (IBD), comprised of Crohn's disease and ulcerative colitis, is a chronic, relapsing, and remitting disease of the gastrointestinal tract whose incidence is rising worldwide, especially in East Asian countries. The etiopathogenesis of IBD remains poorly understood. It is currently considered that a combination of genetic and environmental factors triggers an aberrant immune response against the commensal intestinal flora in IBD patients. Over the past decades, advances in the knowledge of the inflammatory cascade involved in IBD pathogenesis have expanded the pharmacological armamentarium in IBD. Actually, the introduction of specific biological therapies, including anti- tumor necrosis factor, anti-interleukin-12/23, and anti-integrin, has revolutionized the treatment of IBD. Moreover, small molecule agents such as Janus kinase inhibitors also now under clinical use. In IBD, a substantial number of patient accompanies various articular manifestations and, rheumatic involvement is one of the most common extra-intestinal symptoms. Many of the mechanisms based drugs described above have already been used in rheumatic diseases. In addition, some of those drugs can be used to treat both IBD itself and accompanied rheumatic involvement, however there are differences in drug usage between these two indications. This review aims to briefly review the mechanism-based drug therapies of IBD with particular reference to rheumatic disease. (J Rheum Dis 2020;27:128-135)
\end{abstract}

Key Words. Inflammatory bowel disease, Crohn's disease, Ulcerative colitis, Pathogenesis, Biologics, Small molecule

\section{INTRODUCTION}

Inflammatory bowel disease (IBD), comprised of Crohn's disease (CD) and ulcerative colitis (UC), is a chronic, relapsing and remitting disease of the gastrointestinal tract whose incidence is rising worldwide [1]. The etiology of IBD is unknown but is thought to involve an interplay between genetic susceptibility, altered gut microbiota, and environmental factors that trigger an aberrant immune response to commensal bacteria in the gut [2]. In $\mathrm{CD}$, inflammation can involve any part of the gastrointestinal tract, from the mouth to the anus, and it is typically trans-mural and segmental. The most frequently affected sites are the distal ileum and the colon. Disease course of $\mathrm{CD}$ is often complicated by the development of strictures, fistulas, and abscesses that can neces- sitate surgery [3]. In UC, inflammation begins in the rectum and can extend to the entire colon, and it is typically continuous and more superficial, involving only the mucosa and submucosa [4]. Colon cancer is widely acknowledged as a long-term complication of IBD, possibly as a result of chronic inflammation. In the active phases, IBD patients can manifest diarrhea, abdominal pain, fever, rectal bleeding, and weight loss. The disease course is highly variable by patients. Being a systemic disease, IBD can also be associated with extra-intestinal manifestations, including rheumatological, dermatological, ocular, or hepatic disorders. Between $6 \%$ and $47 \%$ of patients with IBD suffer at least one extra-intestinal manifestation [5].

IBD-related arthropathy is one of a group of inflammatory arthritides considered as spondyloarthritis

Received : December 28, 2019, Revised : (1st) March 23, 2020, (2nd) March 24, 2020, Accepted : March 24, 2020

Corresponding to : Jae Jun Park (iD http://orcid.org/0000-0001-9974-1658

Division of Gastroenterology, Department of Internal Medicine, Yonsei University College of Medicine, 50-1 Yonsei-ro, Seodaemun-gu, Seoul 03722, Korea. E-mail : jaejpark@yuhs.ac 
(SpA), a group of disorders that also includes ankylosing spondylitis, psoriatic arthritis, reactive arthritis, and undifferentiated SpA. IBD-related SpA is mainly characterized by axial involvement but may also be associated with peripheral symptoms, such as synovitis, dactylitis, or enthesitis [6]. According to the meta-analysis for the prevalence of SpA in IBD, peripheral arthritis, sacroiliitis, and ankylosing spondylitis were present in 13, 10, and 3 percent, respectively [7]. Peripheral arthritis occurs in $5 \% \sim 10 \%$ of UC patients and $15 \% \sim 20 \%$ of those with $\mathrm{CD}$. The prevalence of axial involvement is higher in patients with $\mathrm{CD}$ than in UC [8]. Concerning the timing of appearance for axial $\mathrm{SpA}$, it can precede IBD symptoms from $31 \%$ to $50 \%$ of patients. On the other hand, symptoms of axial SpA and IBD can co-occur from $15 \%$ to $40 \%$ of patients [9-12]. Ankylosing spondylitis in patients with IBD runs a clinical course independent of the IBD [13].

Conventional therapeutic options for IBD include 5-aminosalicylates, corticosteroids, thiopurines, methotrexate, which have been used as the initial medications in a step-up approach. In recent years, the field has moved away from nonspecific immunosuppression towards a pathway-based anti-inflammatory approach. Several biologic (antibody) agents and small molecules have become available that target specific contributors to the pathophysiology of IBD, including tumor necrosis factor (TNF)-alpha, interleukin (IL)-12/IL-23, alpha4 beta7 $(\alpha 4 \beta 7)$ integrin, and Janus kinase (JAK)/signal transducers and activators of transcription (STAT). In this review, a brief overview of mechanism-based drug therapies of IBD with particular reference to rheumatic disease will be discussed.

\section{MAIN SUBJECTS}

\section{Mechanism-based drug therapies for IBD: biologics and small molecule}

Multiple studies suggest that IBD results from a dysregulated response by the mucosal immune system to the microbiota that resides within the intestinal lumen. This dysregulation can be both due to excessive immune reactivity and to inadequate immune responses to intestinal microbiota, highlighting the importance of a balanced immune response. Alterations in intestinal mucus, high numbers of bacteria within the mucus, and increased intestinal permeability have been associated with IBD [14-17]. Over the past decades, advances in the knowledge of the inflammatory cascade involved in IBD pathogenesis have expanded the pharmacological therapeutics in IBD. Therapeutic strategies targeting specific molecule and inflammatory pathways have emerged as a crucial therapeutic strategy in IBD patients who are refractory or relapsing to conventional therapies $[18,19]$.

\section{Cytokine blockade}

\section{1) TNF inhibitors}

$\mathrm{TNF}$ is one of the major proinflammatory cytokines involved in the pathogenesis of IBD. TNF is produced by a variety of mucosal cells, mainly macrophages and $\mathrm{T}$ cells, as a preform on the plasma membrane [20]. The transmembrane precursor form TNF (mTNF) is cleaved by the converting enzyme into a soluble form (sTNF) [21]. There are two forms of TNF receptor, including $55-\mathrm{kDa}$ TNFR1 and 75-kDa TNFR2, and both forms are biologically active. Signal transduction of the membranebound form of TNF can be transmitted through both TNFR1 and TNFR2, whereas sTNF mainly signals through TNFR1 [22]. The downstream signaling cascade of the TNF receptor involves cell proliferation, cytokine secretion, or apoptosis [23].

TNF inhibitors are the first biologic agents introduced for the treatment of IBD. In 1997, a first controlled study showing the efficacy of infliximab in $\mathrm{CD}$ patients was reported by Targan et al. [24]. Infliximab is a chimeric monoclonal antibody against TNF-alpha comprised of $75 \%$ human and $25 \%$ murine sequences. The efficacy of infliximab was demonstrated in placebo-controlled trials, both CD $[25,26]$ and UC [27] patients who do not respond to conventional therapies. In the past decade, other subcutaneous TNF inhibitors have become available. Adalimumab, a fully human monoclonal antibody, has been shown to induce and maintain remission in moderate-to-severe CD [28,29] and UC [30,31]. Moreover, golimumab, a fully human antibody, demonstrated its efficacy inducing and maintaining clinical response and remission in patients with moderate-to-severe UC [32]. Usually, higher dosages are used for IBD patients, and the details of drug dosage of these three TNF inhibitors for IBD are as follows; 1 ) infliximab, induction dose: intravenous (IV) $5 \mathrm{mg} / \mathrm{kg}$ (weeks 0,2 , and 6 weeks), maintenance dose: $5 \mathrm{mg} / \mathrm{kg}$ every 8 weeks; 2) adalimumab, induction dose: subcutaneous (SC) $160 \mathrm{mg}$ (week 0), $80 \mathrm{mg}$ (week 2), maintenance dose: $40 \mathrm{mg}$ every 2 weeks; 3 ) golimumab, induction dose: SC $200 \mathrm{mg}$ (week 0), $100 \mathrm{mg}$ (week 2), maintenance dose: $100 \mathrm{mg}$ every 4 weeks. Dose 
intensification is available when the response is lost for infliximab (10 mg/kg every 8 weeks) in CD and adalimumab (40 mg weekly) in CD and UC.

These three types of anti-TNF agents have also been approved in adult rheumatic diseases, including rheumatoid arthritis, psoriatic arthritis, and ankylosing spondylitis. The details of drug dosage for these three TNF inhibitors are as follows; 1) Infliximab: rheumatoid arthritis (in combination with methotrexate therapy): IV $3 \mathrm{mg} / \mathrm{kg}$ at 0,2 , and 6 weeks, followed by $3 \mathrm{mg} / \mathrm{kg}$ every 8 weeks thereafter; Psoriatic arthritis (with or without methotrexate): IV $5 \mathrm{mg} / \mathrm{kg}$ at 0,2 , and 6 weeks, followed by $5 \mathrm{mg} / \mathrm{kg}$ every 8 weeks thereafter; Ankylosing spondylitis: IV 5 $\mathrm{mg} / \mathrm{kg}$ at 0,2 , and 6 weeks, followed by $5 \mathrm{mg} / \mathrm{kg}$ every 6 weeks thereafter. 2) Adalimumab: Rheumatoid arthritis: SC $40 \mathrm{mg}$ every other week (may continue methotrexate, other nonbiologic disease-modifying anti-rheumatic drugs (DMARDs), corticosteroids, nonsteroidal anti-inflammatory drugs (NSAIDs), and/or analgesics); patients not taking concomitant methotrexate may increase the dose to 40 mg every week; Psoriatic arthritis and ankylosing spondylitis: SC $40 \mathrm{mg}$ every other week (may continue methotrexate, other nonbiologic DMARDs, corticosteroids, NSAIDs and/or analgesics) 3) Golimumab: Rheumatoid arthritis, psoriatic arthritis, ankylosing spondylitis: IV $2 \mathrm{mg} / \mathrm{kg}$ at weeks 0,4 , and then every 8 weeks thereafter (in combination with methotrexate), SC $50 \mathrm{mg}$ once a month (in combination with methotrexate). Meanwhile, unlike the TNF inhibitors mentioned above, which are monoclonal antibody to TNF targeting both sTNF and mTNF forms, etanercept, a fully soluble, human dimeric fusion protein functions as a TNF inhibitor by competitively binding to TNF, failed to show efficacy in $\mathrm{CD}$ [33]. This finding suggests that blocking sTNF alone has no therapeutic effect in IBD [34].

\section{2) IL-12/IL-23 blockers}

Recent concepts for the pathophysiology of IBD suggest a disturbed adaptive immune response, with an excessive $\mathrm{T}$ helper-1 (Th1) immune reaction, especially in $\mathrm{CD}$. IL-12 is the main inducer of Th1 immune responses in $\mathrm{CD}$ [35] and is produced predominantly by monocytes/ macrophages in response to bacterial stimulation [36]. Moreover, it has been implicated that the innate immune system and the IL-23/T helper-17 (Th17) axis as being crucial in the pathogenesis of IBD. Activation of IL-23, with its subunits $\mathrm{p} 19$ and $\mathrm{p} 40$, triggers the differentiation of naïve T cells into Th17 cells, which then produce IL-17, and IL-21, thereby suppressing regulatory T-cell activity [37].

Ustekinumab is a fully human monoclonal antibody that blocks the p40 subunit of IL-12/IL-23. Randomized trials confirmed the efficacy of ustekinumab inducing remission and maintaining remission in moderate to severe $\mathrm{CD}$ patients who failed to conventional agents or anti-TNF therapies [38]. Recently, ustekinumab also showed efficacy in moderate-to-severe UC patients, and it was approved for UC [39]. Several other types of a humanized monoclonal antibody that selectively targets the p19 subunit of IL-23 are under investigation in IBD [40-42]. The details of drug dosage and route of administration for ustekinumab are as follows; induction (IV route): $\leq 55 \mathrm{~kg}$ : $260 \mathrm{mg}, 55 \sim 85 \mathrm{~kg}: 390 \mathrm{mg},>85 \mathrm{~kg}: 520 \mathrm{mg}$, maintenance (SC route): $90 \mathrm{mg}$ every 12 or 8 weeks. On the other hand, ustekinumab has also been approved for psoriatic arthritis. The details of drug dosage for ustekinumab are as follows: initial and maintenance: SC $45 \mathrm{mg}$ at 0 and 4 weeks, and then every 12 weeks thereafter (when used for psoriatic arthritis, may be administered alone or in combination with methotrexate). Meanwhile, studies evaluating the efficacy of ustekinumab in active AS patients were stopped because ustekinumab did not achieve key outcome endpoints [43,44].

\section{3) IL-17 blockers}

IL-17 induces the recruitment of immune cells to peripheral tissues, an effect that requires nuclear factor kappa B (NF-kB) activation after IL-17 receptor engagement. IL-17 also leads to the induction of many proinflammatory factors, including TNF-alpha, IL-6, IL-23, and IL-1b by innate immune cells and antigen-presenting cells [45]. Elevated fecal IL-17A levels were described in active CD, and IL-17A producing cells within the lamina propria were higher in $\mathrm{CD}$ than in control group [46]. Meanwhile, clinical trials that evaluated secukinumab, a fully human anti-IL-17A monoclonal antibody, in CD patients showed no efficacy, and, in fact, some patients developed disease worsening [47]. Regarding this negative and even paradoxical response, data have suggested that, in addition to proinflammatory activities, IL-17 has essential roles in intestinal barrier function, which may have precluded clinical efficacy with anti-IL-17 targeted therapies in CD [48]. Given the current approved use of secukinumab in several rheumatologic diseases, including psoriatic arthritis and ankylosing spondylitis, caution may be needed when using it in patients who accompanied by $\mathrm{CD}$. 


\section{4) IL-6 blockers}

IL-6 has multiple proinflammatory effects, and its production is upregulated in CD patients [37], accordingly, IL-6 targeting therapy was evaluated in IBD. Tocilizumab, a humanized monoclonal antibody to IL- 6 receptor that is now used in rheumatoid arthritis and adult-onset Still disease, has been investigated in a randomized pilot trial in active $\mathrm{CD}$. In this trial, although tocilizumab demonstrated a higher clinical response rate compared with placebo, neither endoscopic nor histological healing was observed [49]. Due to this reason, no further trials of tocilizumab in $\mathrm{CD}$ were performed. Another fully human monoclonal antibody neutralizing IL-6, PF-04236921, was also evaluated in $\mathrm{CD}$ patients who failed anti-TNF therapy and showed efficacy in inducing clinical remission [50]. However, gastrointestinal abscesses and perforation were observed with PF-04236921 treated patients. Although most perforations occurred in patients having diverticulitis and previously taking NSAIDs, this adverse event may limit a wide spread of IL- 6 antagonists and requires special attention in future clinical trials.

\section{Anti-trafficking therapies}

After activation of the innate and adaptive immune response by luminal contents and intestinal microbes, multiple inflammatory mediators are released and recruit further activated immune cells. The maintenance of the constant inflammatory response in the mucosa is supported by the migration and homing of activated lymphocytes and monocytes into the inflamed mucosa [51]. Leukocytes roll along the vascular endothelium and transmigrate through the endothelium to the inflamed mucosa. During this process, the interaction between cell-expressed integrins on the surface of leukocytes and tissue-expressed adhesion molecules on the vascular endothelium is pivotal in attaining the adhesion of a leukocyte to endothelial cells [51].

Vedolizumab is a humanized monoclonal antibody that blocks the entire $\alpha 4 \beta 7$ integrins in the gastrointestinal tract. Vedolizumab is not typically associated with systemic effect because it interferes with lymphocyte trafficking limited to the gastrointestinal tract. Vedolizumab demonstrated clinical efficacy based on placebo-controlled trials in terms of induction and maintenance therapies in both moderate-to-severe UC [52] and CD [53]. The details of drug dosage and route of administration for vedolizumab are as follows; induction (IV route): $300 \mathrm{mg}$ (weeks 0,2 , and 6 weeks), maintenance
(IV route): $300 \mathrm{mg}$ every 8 weeks. Dose intensification (300 mg every 4 weeks) is available when the response is lost. On the other hands, although natalizumab, a monoclonal antibody directed against the $\alpha 4$ subunit, inhibits gut and brain lymphocyte migration through blocking $\alpha 4 \beta 7$ and $\alpha 4 \beta 1$ integrin-mediated interactions showed efficacy in moderate to severe $\mathrm{CD}$, a serious adverse event of progressive multifocal leukoencephalopathy limited its use [54,55].

Although theoretically, vedolizumab is a drug-specific for intestine, thus it will have no or less effect on articular manifestations, there have been concerns regarding the influence of vedolizumab on articular manifestations in patients with IBD-associated SpA yielding controversial results. Regarding this issue, several data reported a beneficial effect of vedolizumab use on extra-intestinal manifestations such as articular manifestations and SpA [56-58]. By contrast, several case series reported new-onset or exacerbated arthritis and sacroilitis in patients treated with vedolizumab [59-61]. Currently, it seems that vedolizumab at least has no influence on articular manifestations in patients with SpA associated with IBD, and the onset of rheumatic manifestations may be related to the unmasking effect of vedolizumab for latent SpA which was quiescent during previous anti-TNF therapy $[62,63]$.

Other than anti-integrin therapy, other anti-trafficking therapies using sphingosine-1-phosphate receptor modulators such as ozanimod and etrasimod are under investigation in UC [64]. Sphingosine-1-phosphate (S1P) is a signaling molecule that regulates the traffic of lymphocytes out of the lymphoid organs into the bloodstream and to inflamed tissue.

\section{JAK inhibitors}

JAKs play a central role in the innate and adaptive immune response. Most cytokines involved in the IBD pathogenesis signal through the JAK/STAT pathway. Proinflammatory cytokines that signal through the JAK/STAT pathway include interleukins IL-2, IL-6, IL-12, IL-23, and IFN-gamma; meanwhile, cytokines not using the JAK/STAT pathway include TNF, IL-1, IL-8, TGF- $\beta$, and macrophage colony-stimulating factor [65]. At present, four JAKs, including JAK1, JAK2, JAK3, tyrosine kinase 2 (TYK2), as well as seven STATs, that is, STAT1, STAT2, STAT3, STAT4, STAT5A, STAT5B, and STAT6 have been found in humans. The blockade of the JAK/STAT pathway inhibits the activity of multiple cytokines simultaneously, 
and it has been investigated in IBD therapy [66].

Tofacitinib is an orally administered pan JAK inhibitor, and it potently inhibits JAK1, JAK2, and JAK3 and, to a lesser extent, TYK2 [67]. Three-phase III trials with tofacitinib confirmed its efficacy in induction and maintenance therapy compared to placebo in patients with moderately to severe UC [66]. On the other hand, tofacitinib failed in showing efficacy in moderate to severe $\mathrm{CD}$ patients [68]. Other selective JAK inhibitors, including filgotinib (JAK 1 inhibitor), upadacitinib (JAK 1 inhibitor), and peficitinib (JAK 3 inhibitor) are under active investigations in IBD [69-71]. JAK inhibitors are small molecules which differ from other antibody-based biologics in several aspects. Compared with biologic agents, small molecules have advantages in terms of lower risk of immunogenicity and orally administered medication [72]. The details of drug dosage for tofacitinib are as follows; induction: $10 \mathrm{mg}$ bis in die (bid), maintenance: 5 or
$10 \mathrm{mg}$ bid. Meanwhile, tofacitinib has also been approved for use in rheumatoid arthritis. The dosing schedule in rheumatoid arthritis is $5 \mathrm{mg}$ twice daily (monotherapy or in combination with nonbiologic DMARDs).

\section{Interdisciplinary approach between gastroenterologist and rheumatologist}

Most biologics and small molecule agents described above have already been used in the disease of rheumatologic area, as well as IBD. Although the route and frequency of administration are similar between IBD and rheumatologic disease, the dosages of the drugs are different between these diseases. In general, drug dosages are higher in IBD than in rheumatologic disease when the same drug is used; therefore, if the above mentioned single drug is used as multiple indications for both IBD and rheumatologic disease, it is necessary to confirm drug dosage. Indications and dosages of the biologics and

Table 1. Currently approved biologics and small molecule for adult patients with inflammatory bowel disease in Korea

\begin{tabular}{|c|c|c|c|c|c|}
\hline Mechanism & Drug & Route & $\begin{array}{l}\text { Indications } \\
\text { of IBD }\end{array}$ & Approved dose in IBD & $\begin{array}{l}\text { Indications of } \\
\text { rheumatic disease }\end{array}$ \\
\hline \multirow[t]{3}{*}{ Anti-TNF } & Infliximab & IV & $C D$ and $U C$ & $\begin{array}{l}\text { - Induction: } 5 \mathrm{mg} / \mathrm{kg} \text { (weeks } 0,2 \text {, and } 6 \text { weeks) } \\
\text { - Maintenance: } 5 \mathrm{mg} / \mathrm{kg} \text { every } 8 \text { weeks } \\
\text { - Dose intensification ( } 10 \mathrm{mg} / \mathrm{kg} \text { every } 8 \\
\text { weeks) is available when the response is } \\
\text { lost in CD. }\end{array}$ & RA, AS, PsA, PsO \\
\hline & Adalimumab & SC & $\begin{array}{l}C D, U C \text {, and } \\
\text { intestinal BD }\end{array}$ & $\begin{array}{l}\text { - Induction: } 160 \text { mg (week 0), } 80 \text { mg (week 2) } \\
\text { - Maintenance: } 40 \text { mg every } 2 \text { weeks } \\
\text { - Dose intensification ( } 40 \text { mg weekly) is } \\
\text { available when the response is lost in CD, } \\
\text { UC, and intestinal BD. }\end{array}$ & $\begin{array}{l}\mathrm{RA}, \mathrm{AS}, \mathrm{PsA}, \mathrm{PsO} \\
\text { nr-axSpA, UV, HS }\end{array}$ \\
\hline & Golimumab & SC & UC & $\begin{array}{l}\text { - Induction: } 200 \text { mg (weeks 0), } \\
100 \text { mg (week 2) } \\
\text { - Maintenance: } 100 \text { mg every } 4 \text { weeks }\end{array}$ & $\begin{array}{l}\text { RA, AS, PsA, } \\
\text { nr-axSpA }\end{array}$ \\
\hline Anti-IL-12/23 (p40) & Ustekinumab & $\begin{array}{l}\text { IV } \\
\text { SC }\end{array}$ & $\mathrm{CD}$ and $\cup C$ & $\begin{array}{l}\text { - Induction (IV): } \leq 55 \mathrm{~kg}: 260 \mathrm{mg} \\
\text { 55 } 85 \mathrm{~kg}: 390 \mathrm{mg} \\
>85 \mathrm{~kg}: 520 \mathrm{mg}\end{array}$ & $\begin{array}{l}\text { PsA (2nd line), } \\
\text { PsO (1st line) }\end{array}$ \\
\hline Anti- $\alpha 4 \beta 7$ integrin & Vedolizumab & IV & $\mathrm{CD}$ and UC & $\begin{array}{l}\text { - Induction: } 300 \text { mg (weeks 0, 2, and } 6 \text { weeks) } \\
\text { - Maintenance: } 300 \text { mg every } 8 \text { weeks } \\
\text { - Dose intensification ( } 300 \text { mg every } 4 \\
\text { weeks) is available when the response is } \\
\text { lost in CD and UC. }\end{array}$ & $\begin{array}{l}\text { No indication is } \\
\text { approved }\end{array}$ \\
\hline JAK inhibitor & Tofacitinib & $\mathrm{PO}$ & UC & $\begin{array}{l}\text { - Induction: } 10 \mathrm{mg} \text { bid } \\
\text { - Maintenance: } 5 \sim 10 \mathrm{mg} \text { bid }\end{array}$ & RA \\
\hline
\end{tabular}

IBD: inflammatory bowel disease, TNF: tumor necrosis factor, IL: interleukin, JAK: Janus kinase, IV: intravenous, SC: subcutaneous, PO: per oral, CD: Crohn's disease, UC: Ulcerative colitis, BD: Behçet's disease, bid: bis in die, RA: rheumatoid arthritis, AS: ankylosing spondylitis, PsA: psoriatic arthritis, PsO: plaque psoriasis, nr-axSpA: Non-radiographic axial spondyloarthritis, UV: uveitis, HS: Hidradenitis suppurativa. 
small-molecule agents for IBD and rheumatic diseases, which are approved in Korea, are summarized in Table 1.

On the other hand, some rheumatological drugs such as secukinumab may exert a negative impact on IBD outcomes. Moreover, although not covered in this review, NSAIDs, the most commonly used analgesia in rheumatic diseases, are relatively contraindicated in patients with IBD for concern of disease aggravation. Thus, although safety has not yet been completely established, the use of selective cyclooxygenase 2 inhibitors for the treatment of rheumatological manifestations of IBD may be considered as an alternative to NSAIDs [73]. Considering the above-mentioned issues, close partnership between rheumatologists and gastroenterologists is needed to maximize the therapeutic effect and minimize adverse effects in the treatment of rheumatic manifestations of IBD.

\section{CONCLUSION}

IBD is increasing worldwide, and the increase is steep, especially in East Asian countries. The etiology of IBD is still unclear; however, it is presumed to be a combination of genetic factors, environmental factors, and abnormal immune responses to intestinal microflora. Recent advances in knowledge for disease mechanism and pharmaceutical techniques led to the introduction of more sophisticated drugs that target specific molecule and pathway, and it expended therapeutic options in IBD. A substantial number of IBD patients accompany extraintestinal manifestation, including rheumatologic features. In IBD patients having rheumatic involvement, a single agent can be used with indications for both IBD and rheumatic manifestation. Clinicians are needed to be cautious when using a drug for overlapping indication since the administration details can be different depending on the disease. In addition, some medications used in rheumatic disease may precipitate disease exacerbation of IBD. In this regard, communication and close collaboration between gastroenterologists and rheumatologists may be highly needed, and it will help to improve the clinical outcomes of patients.

\section{CONFLICT OF INTEREST}

No potential conflict of interest relevant to this article was reported.

\section{REFERENCES}

1. Ng SC, Shi HY, Hamidi N, Underwood FE, Tang W, Benchimol EI, et al. Worldwide incidence and prevalence of inflammatory bowel disease in the 21st century: a systematic review of population-based studies. Lancet 2018;390:2769-78.

2. Xavier RJ, Podolsky DK. Unravelling the pathogenesis of inflammatory bowel disease. Nature 2007;448:427-34.

3. Torres J, Mehandru S, Colombel JF, Peyrin-Biroulet L. Crohn's disease. Lancet 2017;389:1741-55.

4. Ungaro R, Mehandru S, Allen PB, Peyrin-Biroulet L, Colombel JF. Ulcerative colitis. Lancet 2017;389:1756-70.

5. Ott C, Schölmerich J. Extraintestinal manifestations and complications in IBD. Nat Rev Gastroenterol Hepatol 2013;10:585-95.

6. Atzeni F, Defendenti C, Ditto MC, Batticciotto A, Ventura $\mathrm{D}$, Antivalle $\mathrm{M}$, et al. Rheumatic manifestations in inflammatory bowel disease. Autoimmun Rev 2014;13:20-3 .

7. Karreman MC, Luime JJ, Hazes JMW, Weel AEAM. The prevalence and incidence of axial and peripheral spondyloarthritis in inflammatory bowel disease: a systematic review and meta-analysis. J Crohns Colitis 2017;11:631-42.

8. Salvarani C, Fries W. Clinical features and epidemiology of spondyloarthritides associated with inflammatory bowel disease. World J Gastroenterol 2009;15:2449-55.

9. Palm O, Moum B, Ongre A, Gran JT. Prevalence of ankylosing spondylitis and other spondyloarthropathies among patients with inflammatory bowel disease: a population study (the IBSEN study). J Rheumatol 2002;29:511-5.

10. Scarpa R, del Puente A, D'Arienzo A, di Girolamo C, della Valle G, Panarese A, et al. The arthritis of ulcerative colitis: clinical and genetic aspects. J Rheumatol 1992;19:373-7.

11. Dekker-Saeys BJ, Meuwissen SG, Van Den Berg-Loonen EM, De Haas WH, Meijers KA, Tytgat GN. Ankylosing spondylitis and inflammatory bowel disease. III. Clinical characteristics and results of histocompatibility typing (HLA B27) in 50 patients with both ankylosing spondylitis and inflammatory bowel disease. Ann Rheum Dis 1978; 37:36-41.

12. Orchard TR, Wordsworth BP, Jewell DP. Peripheral arthropathies in inflammatory bowel disease: their articular distribution and natural history. Gut 1998;42:387-91.

13. Orchard TR, Jewell DP. Conditions of the eyes and joints associated with inflammatory bowel disease. In: Targan SR, Shanahan F, Karp LC, eds. Inflammatory bowel disease: translating basic science into clinical practice. Chichester, Blackwell, 2010, p. 553-61.

14. Podolsky DK, Isselbacher KJ. Composition of human colonic mucin. Selective alteration in inflammatory bowel disease. J Clin Invest 1983;72:142-53.

15. Schultsz C, Van Den Berg FM, Ten Kate FW, Tytgat GN, Dankert J. The intestinal mucus layer from patients with inflammatory bowel disease harbors high numbers of bacteria compared with controls. Gastroenterology 1999;117:1089-97.

16. Wyatt J, Vogelsang H, Hübl W, Waldhöer T, Lochs $H$. Intestinal permeability and the prediction of relapse in Crohn's disease. Lancet 1993;341:1437-9.

17. Brazil JC, Louis NA, Parkos CA. The role of polymorphonuclear leukocyte trafficking in the perpetuation of inflammation during inflammatory bowel disease. Inflamm 
Bowel Dis 2013;19:1556-65.

18. Park JJ, Yang SK, Ye BD, Kim JW, Park DI, Yoon H, et al.; IBD Study Group of the Korean Association for the Study of Intestinal Diseases. Second Korean guidelines for the management of Crohn's disease. Intest Res 2017;15:38-67.

19. Choi CH, Moon W, Kim YS, Kim ES, Lee BI, Jung Y, et al.; IBD Study Group of the Korean Association for the Study of Intestinal Diseases. Second Korean guidelines for the management of ulcerative colitis. Intest Res 2017;15:7-37.

20. Bradley JR. TNF-mediated inflammatory disease. J Pathol 2008;214:149-60.

21. Slevin SM, Egan LJ. New insights into the mechanisms of action of anti-tumor necrosis factor- $\alpha$ monoclonal antibodies in inflammatory bowel disease. Inflamm Bowel Dis 2015; 21:2909-20.

22. Grell M, Wajant H, Zimmermann G, Scheurich P. The type 1 receptor (CD120a) is the high-affinity receptor for soluble tumor necrosis factor. Proc Natl Acad Sci U S A 1998;95: 570-5.

23. Billmeier U, Dieterich W, Neurath MF, Atreya R. Molecular mechanism of action of anti-tumor necrosis factor antibodies in inflammatory bowel diseases. World J Gastroenterol 2016;22:9300-13.

24. Targan SR, Hanauer SB, van Deventer SJ, Mayer L, Present $\mathrm{DH}$, Braakman T, et al. A short-term study of chimeric monoclonal antibody cA2 to tumor necrosis factor alpha for Crohn's disease. Crohn's Disease cA2 Study Group. N Engl J Med 1997;337:1029-35.

25. Hanauer SB, Feagan BG, Lichtenstein GR, Mayer LF, Schreiber S, Colombel JF, et al.; ACCENT I Study Group. Maintenance infliximab for Crohn's disease: the ACCENT I randomised trial. Lancet 2002;359:1541-9.

26. Sands BE, Anderson FH, Bernstein CN, Chey WY, Feagan BG, Fedorak RN, et al. Infliximab maintenance therapy for fistulizing Crohn's disease. N Engl J Med 2004;350:876-85.

27. Rutgeerts P, Sandborn WJ, Feagan BG, Reinisch W, Olson A, Johanns J, et al. Infliximab for induction and maintenance therapy for ulcerative colitis. N Engl J Med 2005;353: 2462-76

28. Hanauer SB, Sandborn WJ, Rutgeerts P, Fedorak RN, Lukas $\mathrm{M}$, MacIntosh D, et al. Human anti-tumor necrosis factor monoclonal antibody (adalimumab) in Crohn's disease: the CLASSIC-I trial. Gastroenterology 2006;130:323-33; quiz 591.

29. Colombel JF, Sandborn WJ, Rutgeerts P, Enns R, Hanauer $\mathrm{SB}$, Panaccione R, et al. Adalimumab for maintenance of clinical response and remission in patients with Crohn's disease: the CHARM trial. Gastroenterology 2007;132: 52-65.

30. Sandborn WJ, van Assche G, Reinisch W, Colombel JF, D'Haens G, Wolf DC, et al. Adalimumab induces and maintains clinical remission in patients with moderate-to-severe ulcerative colitis. Gastroenterology 2012;142:257-65.e1-3.

31. Reinisch W, Sandborn WJ, Hommes DW, D'Haens G, Hanauer S, Schreiber S, et al. Adalimumab for induction of clinical remission in moderately to severely active ulcerative colitis: results of a randomised controlled trial. Gut 2011; 60:780-7.

32. Sandborn WJ, Feagan BG, Marano C, Zhang H, Strauss R, Johanns J, et al.; PURSUIT-SC Study Group. Subcutaneous golimumab induces clinical response and remission in pa- tients with moderate-to-severe ulcerative colitis. Gastroenterology 2014;146:85-95; quiz e14-5.

33. Sandborn WJ, Hanauer SB, Katz S, Safdi M, Wolf DG, Baerg $\mathrm{RD}$, et al. Etanercept for active Crohn's disease: a randomized, double-blind, placebo-controlled trial. Gastroenterology 2001;121:1088-94.

34. Van den Brande JM, Koehler TC, Zelinkova Z, Bennink RJ, te Velde AA, ten Cate FJ, et al. Prediction of antitumour necrosis factor clinical efficacy by real-time visualisation of apoptosis in patients with Crohn's disease. Gut 2007;56: 509-17.

35. Monteleone G, Biancone L, Marasco R, Morrone G, Marasco $\mathrm{O}$, Luzza F, et al. Interleukin 12 is expressed and actively released by Crohn's disease intestinal lamina propria mononuclear cells. Gastroenterology 1997;112:1169-78.

36. Trinchieri G. Interleukin-12: a cytokine produced by antigen-presenting cells with immunoregulatory functions in the generation of T-helper cells type 1 and cytotoxic lymphocytes. Blood 1994;84:4008-27.

37. Neurath MF. Cytokines in inflammatory bowel disease. Nat Rev Immunol 2014;14:329-42.

38. Feagan BG, Sandborn WJ, Gasink C, Jacobstein D, Lang Y, Friedman JR, et al.; UNITI-IM-UNITI Study Group. Ustekinumab as induction and maintenance therapy for Crohn's disease. N Engl J Med 2016;375:1946-60.

39. Sands BE, Sandborn WJ, Panaccione R, O'Brien CD, Zhang H, Johanns J, et al.; UNIFI Study Group. Ustekinumab as induction and maintenance therapy for ulcerative colitis. N Engl J Med 2019;381:1201-14.

40. Feagan BG, Panés J, Ferrante M, Kaser A, D’Haens GR, Sandborn WJ, et al. Risankizumab in patients with moderate to severe Crohn's disease: an open-label extension study. Lancet Gastroenterol Hepatol 2018;3:671-80.

41. Sands BE, Chen J, Feagan BG, Penney M, Rees WA, Danese S, et al. Efficacy and safety of MEDI2070, an antibody against interleukin 23 , in patients with moderate to severe Crohn's disease: a phase 2a study. Gastroenterology 2017; 153:77-86.e6.

42. Sandborn WJ, Ferrante M, Bhandari BR, Berliba E, Feagan BG, Hibi T, et al. Efficacy and safety of mirikizumab in a randomized phase 2 study of patients with ulcerative colitis. Gastroenterology 2020;158:537-49.e10.

43. Janssen Research \& Development, LLC. A study to evaluate the efficacy and safety of ustekinumab in the treatment of anti-TNF(alpha) refractory participants with active radiographic axial spondyloarthritis [Internet]. Bethesda: U.S. National Library of Medicine, 2019 Aug 28 [cited 2020 Mar]. Available from: https://clinicaltrials.gov/ct2/show/ NCT02438787.

44. Janssen Research \& Development, LLC. An efficacy and safety study of ustekinumab in participants with active nonradiographic axial spondyloarthritis [Internet]. Bethesda: U.S. National Library of Medicine, 2019 Mar 13 [cited 2020 Mar]. Available from: https://clinicaltrials.gov/ct2/show/ NCT02407223.

45. Witowski J, Książek K, Jörres A. Interleukin-17: a mediator of inflammatory responses. Cell Mol Life Sci 2004;61: 567-79.

46. Hölttä V, Klemetti P, Sipponen T, Westerholm-Ormio M, Kociubinski G, Salo H, et al. IL-23/IL-17 immunity as a hallmark of Crohn's disease. Inflamm Bowel Dis 2008;14: 
1175-84.

47. Hueber W, Sands BE, Lewitzky S, Vandemeulebroecke M, Reinisch W, Higgins PD, et al.; Secukinumab in Crohn's Disease Study Group. Secukinumab, a human anti-IL-17A monoclonal antibody, for moderate to severe Crohn's disease: unexpected results of a randomised, double-blind placebo-controlled trial. Gut 2012;61:1693-700.

48. Lee JS, Tato CM, Joyce-Shaikh B, Gulen MF, Cayatte C, Chen $Y$, et al. Interleukin-23-independent IL-17 production regulates intestinal epithelial permeability. Immunity 2015; 43:727-38.

49. Ito H, Takazoe M, Fukuda Y, Hibi T, Kusugami K, Andoh A, et al. A pilot randomized trial of a human anti-interleukin- 6 receptor monoclonal antibody in active Crohn's disease. Gastroenterology 2004;126:989-96; discussion 947.

50. Danese S, Vermeire S, Hellstern P, Panaccione R, Rogler G, Fraser $\mathrm{G}$, et al. Randomised trial and open-label extension study of an anti-interleukin- 6 antibody in Crohn's disease (ANDANTE I and II). Gut 2019;68:40-8.

51. Zundler S, Neurath MF. Novel insights into the mechanisms of gut homing and antiadhesion therapies in inflammatory bowel diseases. Inflamm Bowel Dis 2017;23: 617-27.

52. Feagan BG, Rutgeerts P, Sands BE, Hanauer S, Colombel JF, Sandborn WJ, et al.; GEMINI 1 Study Group. Vedolizumab as induction and maintenance therapy for ulcerative colitis. N Engl J Med 2013;369:699-710.

53. Sandborn WJ, Feagan BG, Rutgeerts P, Hanauer S, Colombel JF, Sands BE, et al.; GEMINI 2 Study Group. Vedolizumab as induction and maintenance therapy for Crohn's disease. $\mathrm{N}$ Engl J Med 2013;369:711-21.

54. Lichtenstein GR, Hanauer SB, Sandborn WJ. Risk of biologic therapy-associated progressive multifocal leukoencephalopathy: use of the JC virus antibody assay in the treatment of moderate-to-severe Crohn's disease. Gastroenterol Hepatol (N Y) 2012;8(11 Suppl 8):1-20.

55. Sandborn WJ, Yednock TA. Novel approaches to treating inflammatory bowel disease: targeting alpha-4 integrin. Am J Gastroenterol 2003;98:2372-82.

56. Tadbiri S, Peyrin-Biroulet L, Serrero M, Filippi J, Pariente B, Roblin X, et al.; GETAID OBSERV-IBD study group. Impact of vedolizumab therapy on extra-intestinal manifestations in patients with inflammatory bowel disease: a multicentre cohort study nested in the OBSERV-IBD cohort. Aliment Pharmacol Ther 2018;47:485-93.

57. Orlando A, Orlando R, Ciccia F, Renna S, Rizzo A, Cottone $\mathrm{M}$, et al. Clinical benefit of vedolizumab on articular manifestations in patients with active spondyloarthritis associated with inflammatory bowel disease. Ann Rheum Dis 2017;76:e31.

58. Feagan BG, Sandborn WJ, Colombel JF, Byrne SO, Khalid $\mathrm{JM}$, Kempf C, et al. Incidence of arthritis/arthralgia in inflammatory bowel disease with long-term vedolizumab treatment: post hoc analyses of the GEMINI trials. J Crohns Colitis 2019;13:50-7.

59. Varkas G, Thevissen K, De Brabanter G, Van Praet L, Czul-Gurdian F, Cypers H, et al. An induction or flare of arthritis and/or sacroiliitis by vedolizumab in inflammatory bowel disease: a case series. Ann Rheum Dis 2017;76:
878-81.

60. Wendling D, Sondag M, Verhoeven F, Vuitton L, Koch S, Prati C. Arthritis occurrence or reactivation under Vedolizumab treatment for inflammatory bowel disease. A four cases report. Joint Bone Spine 2018;85:255-6.

61. Dubash S, Marianayagam T, Tinazzi I, Al-Araimi T, Pagnoux C, Weizman AV, et al. Emergence of severe spondyloarthropathy-related entheseal pathology following successful vedolizumab therapy for inflammatory bowel disease. Rheumatology (Oxford) 2019;58:963-8.

62. Tamanini S, Fredi M, Crisafulli F, Lazzaroni MG, Tincani A, Franceschini F. Letter to editor: new onset/recurrence of inflammatory arthralgia/spondyloarthritis in patients treated with vedolizumab for intestinal bowel disease. Clin Rheumatol 2019;38:609-10.

63. Paccou J, Nachury M, Duchemin C, Desreumaux P, Flipo RM, Pariente B. Vedolizumab has no efficacy on articular manifestations in patients with spondyloarthritis associated with inflammatory bowel disease. Joint Bone Spine 2019;86:654-6.

64. Peyrin-Biroulet L, Christopher R, Behan D, Lassen C. Modulation of sphingosine-1-phosphate in inflammatory bowel disease. Autoimmun Rev 2017;16:495-503.

65. Baker SJ, Rane SG, Reddy EP. Hematopoietic cytokine receptor signaling. Oncogene 2007;26:6724-37.

66. Sandborn WJ, Su C, Panes J. Tofacitinib as induction and maintenance therapy for ulcerative colitis. N Engl J Med 2017;377:496-7.

67. Currie KS, Patel L, Sedillo KF. Small-molecule agents for the treatment of inflammatory bowel disease. Bioorg Med Chem Lett 2019;29:2034-41.

68. Panés J, Sandborn WJ, Schreiber S, Sands BE, Vermeire S, D'Haens $\mathrm{G}$, et al. Tofacitinib for induction and maintenance therapy of Crohn's disease: results of two phase IIb randomised placebo-controlled trials. Gut 2017;66:1049-59.

69. Vermeire S, Schreiber S, Petryka R, Kuehbacher T, Hebuterne $\mathrm{X}$, Roblin X, et al. Clinical remission in patients with moderate-to-severe Crohn's disease treated with filgotinib (the FITZROY study): results from a phase 2, double-blind, randomised, placebo-controlled trial. Lancet 2017;389: 266-75.

70. Sandborn WJ, Feagan BG, Panes J, D’Haens GR, Colombel JF, Zhou Q, et al. Safety and efficacy of ABT-494 (upadacitinib), an oral Jak1 inhibitor, as induction therapy in patients with Crohn's disease: results from celest. Gastroenterology 2017;152 Suppl 1:S1308-9.

71. Sands BE, Sandborn WJ, Feagan BG, Lichtenstein GR, Zhang H, Strauss R, et al.; Peficitinib-UC Study Group. Peficitinib, an oral janus kinase inhibitor, in moderate-tosevere ulcerative colitis: results from a randomised, phase 2 study. J Crohns Colitis 2018;12:1158-69.

72. Boland BS, Vermeire S. Janus kinase antagonists and other novel small molecules for the treatment of Crohn's disease. Gastroenterol Clin North Am 2017;46:627-44.

73. Miao XP, Li JS, Ouyang Q, Hu RW, Zhang Y, Li HY. Tolerability of selective cyclooxygenase 2 inhibitors used for the treatment of rheumatological manifestations of inflammatory bowel disease. Cochrane Database Syst Rev 2014;(10):CD007744. 